\title{
INTERNAL GOODS TO LEGAL PRACTICE: RECLAIMING FULLER WITH MACINTYRE
}

\author{
Mark Retter
}

\begin{abstract}
Lon Fuller rejected legal positivism because he believed that the 'procedural morality of law' established a necessary connection between law and morals. Underpinning his argument is a claim that law is a purposive activity grounded by a relationship of political reciprocity between lawgivers and legal subjects. This paper argues that his reliance on political reciprocity implicates a necessary connection between his procedural morality and an unarticulated 'substantive morality of law': it presupposes that law is properly understood by reference to the political task of achieving a common good. To establish this necessary connection, I propose we look to Alasdair MacIntyre. Understanding law as a 'social practice', on MacIntyre's terms, can provide the necessary socio-political context to explain why and how legal practice is conditioned by political reciprocity. If we apply MacIntyre's distinction between the internal and external goods of a social practice, legal positivism can be understood as confusing law as a co-operative social practice with the instrumentalisation of that practice by legal officials.
\end{abstract}

\section{A. INTRODUCTION}

Responding to Fuller's claim that the principles of legality, encapsulated by the rule of law, constitute a procedural morality of law, ${ }^{1}$ Hart wrote:

$[\ldots]$ if this is what the necessary connection of law and morality means, we may accept it. It is unfortunately compatible with very great iniquity. ${ }^{2}$

In a recent book, Rundle describes how the terms of reference in this famous exchange between Hart and Fuller were shifted to whether rule by law is more efficacious for achieving good rather than evil ends. ${ }^{3}$ Fuller's jurisprudential enquiry was indeed focused on the functioning of law as a purposive social activity. However, through his procedural morality, he was trying to reveal how that functioning is constrained by moral principles of legality which constitute what it means to have the rule of law as a system of governance. According to Fuller, law is a rule-governed social practice, and the rules of legality have a distinct moral value. In his view, the debate with Hart was distorted by an instrumentalism that reframed his claims about the distinct moral character of the rule of law into arguments about the moral status of the political ends pursued through law. Hart, on the other hand, believed Fuller was

\footnotetext{
${ }^{*} \mathrm{PhD}$ Candidate and Gates Cambridge Scholar, Trinity Hall, University of Cambridge. I express my gratitude to Dr Nigel Simmonds for his continuing guidance and support. I also thank Alex Green for his helpful comments on this paper.

${ }^{1}$ Lon Fuller, The Morality of Law (Revd edn, Yale University Press 1969); Lon Fuller, 'Positivism and Fidelity to Law - A Reply to Professor Hart' (1958) 71(4) HLR 630.

${ }^{2}$ HLA Hart, The Concept of Law (2nd edn, OUP 1994) 207.

${ }^{3}$ Kristen Rundle, Forms Liberate: Reclaiming the Jurisprudence of Lon L Fuller (Hart Publishing 2013).
} 
failing to adequately distinguish between law as a purposive activity, and the separate question of whether the relevant purposes are necessarily moral. ${ }^{4}$ The art of the torturer, for example, could be said to be a purposive activity governed by principles for success; but those principles are not necessarily moral principles.

Rundle undertakes to 'reclaim' Fuller's jurisprudence from the misunderstandings haunting his debate with Hart; I believe this to be a worthwhile project. ${ }^{5}$ However, this paper argues that we need to go beyond Fuller's own thought if we are to successfully complete his claims against Hart. My argument is that Fuller's procedural morality of law implicates a broader commitment to a political common good as the proper end of law. Underpinning his argument that the functioning of law is constrained by this procedural morality is a claim that legal practice is conditioned by the idea of political reciprocity between a lawgiver and legal subjects. I will show that this 'political reciprocity' makes his procedural morality dependent on a substantive morality of law which he does not adequately develop. The nature of that dependency is uncovered by appreciating the full implications of an internalised and practical viewpoint that captures legal practice as an activity conditioned by the need for the reasons for action of participants to serve as a justification to citizens in a political community. In Fuller's terms, we need to appreciate how the purposive social activity of law provides reasons for fidelity to law and principles of legality if we are to explain law as a recurring social phenomenon through history. ${ }^{6}$

I propose that MacIntyre's teleological conception of social practices and political community provide important resources for this task. The co-operative and purposive nature of legal activity in Fuller's account is captured by appreciating law as a practice, in the sense defined by MacIntyre; an activity involving an extension of skills, virtues and standards of excellence to realise a political order aiming at the common good. ${ }^{7}$ Understanding law in this way requires us to distinguish between the 'internal goods' of legal practice, which can provide a common source of motivation for all participants; and 'external goods', which are

\footnotetext{
${ }^{4}$ HLA Hart, 'Positivism and the Separation of Law and Morals' (1958) 71(4) HLR 593, 606-613, 657-629; HLA Hart, Essays in Jurisprudence and Philosophy (OUP 1983) 349-353.

${ }^{5}$ The reclaiming of Fuller's thought has been the object of much recent attention. See for example: Nigel Simmonds, Law as a Moral Idea (OUP 2007) 70-85; Jeremy Waldron, 'Positivism and Legality: Hart's Equivocal Response to Fuller' (2008) 83 NYULR 1135; Martin Krygier, 'The Hart-Fuller Debate, Transitional Societies and the Rule of Law' in Peter Cane (ed), The Hart Fuller Debate in the Twenty-first Century (Hart Publishing 2009); David Luban, 'The Rule of Law and Human Dignity: Reexamining Fuller's Canons' (2010) 2 Hague Journal on the Rule of Law 29.

${ }^{6}$ Fuller 'Morality of Law' (n 1) 39-41, 106-107, 202-204; Fuller 'Fidelity to Law' (n 1) 632-633, 638-648.

${ }^{7}$ MacIntyre cites law as an example of a social practice: Alasdair MacIntyre, 'Objectivity in Morality and Objectivity in Science' in HT Engelhardt and Daniel Callahan (eds), Moral, Science and Sociality (Hastings-onHudson 1978) 29.
} 
only contingently related to the co-operative ends of the practice. I will consider why this distinction is helpful to establish Fuller's procedural morality of law as a necessary connection between law and morals contrary to Hart's legal positivism.

\section{B. FULLER'S RULE OF LAW AND POLITICAL RECIPROCITY}

We need to first distinguish what Fuller means by procedural legal morality. ${ }^{8}$ Fuller understands law as 'the enterprise of subjecting human conduct to the governance of rules'. That enterprise is a purposive activity conditioned by certain internal standards of success, which define what it means to perform that activity well. He tries to capture these internal standards in eight principles of legality. Rules must be general in nature; promulgated; prospective in application; intelligible; free from conflict and contradiction; possible to comply with; stable through time; and have congruity with official action. ${ }^{10}$ The instantiation of these eight precepts is what constitutes a system of governance as a legal system, and forms an 'internal' or 'procedural' morality to law. Legal systems never perfectly comply with these precepts but are constituted as legal systems to the degree they approximate perfect compliance. ${ }^{11}$

Hart does accept Fuller's eight desiderata as defining features of the rule of recognition, and perhaps minimum criteria for the existence of a legal system. But he disputes their necessary moral significance. ${ }^{12}$ In particular, he criticises Fuller for failing to differentiate between the purposiveness of an activity and its moral significance. ${ }^{13}$ The fact that law is a purposive activity does not establish it as intrinsically moral; just as the art of making poison is not intrinsically moral, although it may involve skills and internal principles that order it towards achieving the poisoner's purposes. These are skills and principles for the efficacy of a craft.

This is a crucial objection if we think that Fuller has not established the internal principles of legal craftsmanship as distinctively moral, compared to other crafts like poisoning. Unfortunately, Fuller's description of the procedural morality partly lends itself to

\footnotetext{
${ }^{8}$ I refer to 'procedural' and 'substantive' morality of law, rather than 'internal' and 'external', to avoid confusion with MacIntyre's 'internal goods' and 'external goods'.

${ }^{9}$ Fuller 'Morality of Law' (n 1) 106.

10 ibid 33-94. I accept Fuller's formulation of the eight desiderata for the purposes of this paper, but I acknowledge potential for debate: Nigel Simmonds, 'Jurisprudence as a Moral and Historical Inquiry' (2005) 18 CJLJ 249, 269-273; Simmonds (n 5) 158-163.

${ }^{11}$ Fuller 'Morality of Law' (n 1) 38-44; Simmonds (n 5) 78-85.

12 Hart (n 2) 206-207.

${ }^{13}$ Hart 'Essays in Jurisprudence and Philosophy' (n 4) 349-351.
} 
an interpretation that would underscore the importance of his principles of legality merely for the efficacy of social control. ${ }^{14}$ He says:

The term 'procedural' is concerned, not with the substantive aims of legal rules, but with the ways in which a system of rules for governing human conduct must be constructed and administered if it is to be efficacious and at the same time remain what it purports to be. ${ }^{15}$

Fuller was concerned to avoid the traditional debate between natural lawyers and positivists about the necessary moral status of the ends of law. ${ }^{16}$ In particular, he was wary of any claim about the existence of some 'higher' natural law, which supersedes contrary positive law. But he was also aware that a focus of jurisprudential enquiry on the ends of law could blur the distinction between political and legal practice. Instead, he was attempting to establish the moral character of the rule of law in a way that would distinguish it from a general consideration of the substantive content of law. ${ }^{17}$ He describes the rule of law as involving principles of good legal craftsmanship that define what it means to construct and administer law well. Not simply as a means for achieving various political ends, but as a particular end or value with moral significance. ${ }^{18}$ This explains why he was so concerned by instrumentalist understandings of the rule of law. They ignore fidelity to law as an end in itself, which justifies the continued existence of, and engagement in, the purposive activity of law. ${ }^{19}$

Let us distinguish more clearly between this procedural morality of law and a substantive morality of law. As a form of political governance, law directs citizens to political ends and binds them to those ends. Through this binding operation, law potentially implicates two interrelated but distinguishable questions that arise from considering how legal subjects may be thought of as morally bound by law. First, there is a substantive morality concerning what ends a community should pursue through law. Second, the binding operation of law raises the moral question for lawmakers concerning how human persons should be bound to the ends of a political community. I stress human person because it is in considering how a human person should be treated, as a subject of moral importance or value, which provides

\footnotetext{
${ }^{14}$ Hart (n 2) 206-207.

${ }^{15}$ Fuller 'Morality of Law' (n 1) 97.

16 ibid 96-97; Fuller 'Fidelity to Law' (n 1) 645-646, 656-660; Lon Fuller, 'Human Purpose and Natural Law' (1956) 53 Journal of Philosophy 697. Fuller is reticent to be associated with natural law because 'the term "natural law" has been so misused on all sides that it is difficult to recapture a dispassionate attitude toward it': ibid 102.

${ }^{17}$ Fuller 'Morality of Law' (n 1) 96-106, 153-155; Fuller 'Fidelity to Law' (n 1) 645-646.

${ }^{18}$ Fuller 'Morality of Law' (n 1) 197, 200-224.

${ }^{19}$ Lon Fuller, 'Means and Ends' in Kenneth Winston (ed), The Principles of Social Order: Selected Essays of Lon L Fuller (Hart Publishing 2001); Rundle (n 3) 34-37, 46-47, 105-108, 193-196.
} 
that question with its moral importance. It is this second question which is the focus of Fuller's procedural morality of law. He wants to identify the eight desiderata as principles of good legal craftsmanship that constitute the rule of law as a morally valuable response to this question of how human persons ought to be bound to communal ends. This leads to the following question. How does Fuller connect his eight desiderata to this moral question, to establish the distinctive moral value of the rule of law as an end in itself?

There are two interdependent themes Fuller associates with the moral status of his eight desiderata. He saw their moral worth as connected firstly to the relationship of political reciprocity between lawgiver and legal subject. ${ }^{20}$ His point is that legal officials are in an interdependent and co-operative relationship with legal subjects. In the first place, the authority to make and administer a system of governance must be justifiable to citizens if it is to form a sustainable political order. There is a mutual need to govern human conduct in a political community which gives rise to a corresponding need for some system of governance. Fuller associates this political context with the substantive morality of law because it 'makes law possible'. ${ }^{21}$ But law is only adopted as a distinct form of governance when the principles of legality are accepted as conditioning what it means to govern well. In other words, the eight desiderata provide standards by which the co-operative relationships required for stable political governance is respected. Compliance with those principles of legality is sustained by the promotion of fidelity to law, which is a reciprocal moral disposition of both legal officials and subjects to act co-operatively to maintain the efficacy of law. Thus, Fuller's principle of reciprocity is supposed to capture the fact that the efficacy of legal practice is sustained by a fidelity to law as a good co-operative means for achieving political ends.

This brings us to the second theme. Fuller points out that, within the context of this political reciprocity, compliance with the eight desiderata enables the law to achieve its function, of subjecting human conduct to general rules, in a way that respects the responsible agency of legal subjects. By satisfying the eight desiderata, legal officials craft and administer the system of law in such a way that citizens are better able to consider what those laws require of them, and to take that into account in deliberating about what they should do in a given context, and in planning how they should live their lives. This provides a basis for saying that the rule of law embodies a moral value because it is intrinsically connected to an

\footnotetext{
${ }^{20}$ Fuller 'Morality of Law' (n 1) 39-40, 106-118, 137-140, 193-194, 203-204, 227-228, 231; Fuller 'Fidelity to Law' (n 1) 645.

${ }^{21}$ Fuller 'Fidelity to Law' (n 1) 645.
} 
appropriate respect for responsible human agency, given that human beings are rational agents with powers of self-determination. ${ }^{22}$ In other words, the rule of law enables political governance to respect human freedom. Fuller links this respect for human agency with an enhancement of respect for human dignity.

Now, it is true that a lot of conceptual detail is missing from Fuller's explanation of the moral value of legality, especially in relation to the nature of human agency and freedom. ${ }^{23}$ Nevertheless, he provides a rough sketch of his procedural legal morality with these two themes of reciprocity and human agency. An important part of his strategy is to distinguish his procedural morality from claims concerning the morality of the substantive political ends of law. Despite these intentions, however, my argument is that his procedural morality does implicate a particularly important inter-dependency with the substantive morality of law which required more detailed consideration to support his arguments against Hart. $^{24}$

Fuller relies on his principle of political reciprocity to establish the respect for human agency as an end internal to the form of that distinct type of governance called law. The reciprocity between lawgiver and legal subject is critical to his argument that legal officials qua legal officials must display fidelity to the rule of law if their form of governance is to be called 'law' and not 'managerial practice' or perhaps 'tyranny'. ${ }^{25}$ This is where Fuller's account presupposes a treatment of legal pathology, which accounts for the way in which a breakdown in political reciprocity will lead to 'bad' legal systems or a failure to even instantiate rule by law. ${ }^{26}$ Without a persuasive articulation of the political theory this presupposes, and its necessary connection to legal practice, Fuller remains open to an attack that depicts his procedural morality as merely incidental to the use of law as a political tool by legal officials. This attack would depict the moral implications of the rule of law as a contingent byproduct of the essential function of law as an instrument for political governance. It is available to Fuller's opponent if they accept the possibility that political systems are not necessarily conditioned by reciprocity.

\footnotetext{
${ }^{22}$ Fuller 'Morality of Law' (n 1) 162-167, 207-224; Lon Fuller, 'A Reply to Professors Cohen and Dworkin' (1965) 10 Villanova Law Review 655, 665.

${ }^{23}$ There are a variety of interpretations of Fuller's thought on the relationship between the rule of law and human agency. See for example: Dan Priel, 'Lon Fuller's Political Jurisprudence of Freedom' (2014) 10(1) JRLS 18; Simmonds (n 5) 99-111; John Finnis, Natural Law and Natural Rights (OUP 1980) 273.

${ }^{24} \mathrm{I}$ do not deny that Fuller recognises the existence of interdependencies. See for example: Fuller 'Morality of Law' (n 1) 152-186, 200-224; Fuller 'Fidelity to Law' (n 1) 645-646. I want to draw out the distinct connection between the procedural morality and the pursuit of a political common good, which is understated in Fuller's treatment of these inter-dependencies.

${ }^{25}$ Fuller 'Morality of Law' (n 1) 33-43, 145-151, 157, 204-223; Fuller 'Fidelity to Law' (n 1) 644-648.

${ }^{26}$ See: Rundle (n 3) 79-80, 94.
} 
This reveals a failure, on Fuller's part, to clearly and fully articulate the dynamic relationship between his procedural morality and the substantive morality of law. In my view, Fuller was right to consider the broader context of political reciprocity as conditioning the reasons for action embedded within legal practice, and therefore the concept of law. However, the sparse treatment of what grounds this reciprocity in political practice left him open to a challenge that would sideline this aspect of his thought as a contingent feature of legal systems and instead focus enquiry on the subjective reasons of legal officials for accepting and applying the rule of law. Kramer, for example, develops Hart's claim that the rule of law has no necessary moral status by arguing that legal officials can adopt a rule of recognition, incorporating the rule of law, as a binding reason for action based on merely self-interested reasons. ${ }^{27}$ The legal subject may simply be given 'the ability and opportunity to obey' in order to achieve the purpose of political control. ${ }^{28}$ This approach underscores the significance of law as an instrument for subjecting human conduct to governance by rules, regardless of whether the rules are adopted for moral or non-moral reasons. Thus, Raz is able to say that Fuller's eight precepts of legality are a virtue of law; but not a moral virtue. ${ }^{29}$ Law does have a function, like a knife, and the principles of legality enhance the efficacy of law for fulfilling that function, like the sharpness of a knife. But they are not intrinsically moral principles because, like a knife, law can be used for both good and evil purposes.

This focus on the subjective reasons of legal officials for adopting the rule of law is crucial. It allows the particular moral significance proposed by Fuller to be characterised as contingent, depending on whether legal officials accept and apply the eight desiderata for moral or non-moral reasons. The eight desiderata can then be seen as enhancing the efficacy of law in achieving political ends because the focus of enquiry has turned to the moral quality of the motivations of legal officials, rather than what would constitute a good reason for action for those officials in the political context entailed by Fuller's understanding of political reciprocity.

In the background to Fuller's notion of political reciprocity is the idea that the value of legality concerns the realisation of the 'rule of law', rather than the 'rule of men'. Fuller is concerned with the embedded nature of legal practice, as a form of good social governance which derives its point and purpose from political community. But he needs to show that this

\footnotetext{
${ }^{27}$ Matthew Kramer, 'On the Moral Status of the Rule of Law' (2004) 63(1) CLJ 65; Matthew Kramer, 'The Big Bad Wolf: Legal Positivism and its Detractors' (2004) 49 AJJ 1; Matthew Kramer, 'Once More Into the Fray: Challenges for Legal Positivism' (2008) 58 UTLJ 1; Matthew Kramer, 'For the Record: A Final Reply to NE Simmonds' (2011) 56 AJJ 115.

${ }^{28}$ Hart (n 2) 207.

${ }^{29}$ Joseph Raz, 'The Rule of Law and its Virtue' in Joseph Raz, The Authority of Law (2nd edn, OUP 2009).
} 
good social governance involves evaluative moral standards that are central to the practical rationality of legal practice, and therefore to the idea of law, in a way that necessarily conditions reasons for action within that practice. But what is it about legal practice that conditions the reasons of officials in that practice? Why should we focus on the reasons that legal officials ought to have in accepting and applying the rule of law, rather than the subjective reasons that they do have?

Fuller is aware that an answer turns on the social role of legal officials within legal practice. ${ }^{30}$ His argument turns on the justificatory basis for the official's role and their consequent commitments within political practice. This explains his emphasis on political reciprocity. He wants to establish that the reasons for action appropriate to this social role are conditioned by socio-political commitments that are necessary features of political community. But he does not adequately consider the nature of these commitments. If those commitments are necessary, then I think Fuller is committed to saying they follow from commitments to achieving a political common good in circumstances of social interdependency. This means Fuller's arguments for a procedural morality of law would presuppose an important dependency on a substantive morality of law, whereby the proper aim of law is the achievement of a political common good.

We need to develop this relationship between the procedural and substantive morality of law in more detail if we are to establish Fuller's necessary connection between law and morals. MacIntyre can help in this endeavour. From MacIntyre's standpoint, the interdependencies between the procedural and substantive morality of law can be uncovered by appreciating law as a 'social practice' in the context of a political community, with socially established reasons for action embedded in its traditions and institutions. With this approach, I will argue that MacIntyre's thought can explain Fuller's moral intuitions about law. He provides resources to elucidate the connections between human agency, the rule of law, and the political common good; these provide a necessary justificatory background to Fuller's procedural morality of law.

\section{SOCIAL PRACTICES AND THE COMMON GOOD}

Fuller thinks jurisprudence implicates an enquiry into why the application of law can be considered by legal officials to have binding authority; and also why legal subjects have good reasons to share this belief and treat law as an obligatory reason for action. Both sides should

\footnotetext{
${ }^{30}$ Fuller 'The Morality of Law' (n 1) 192-193, 216-224.
} 
be in view because the achievement of law's function requires co-operation. Actions on the basis of law are intelligible as intentional human actions when they are justifiable by reference to good reasons for acting. ${ }^{31} \mathrm{We}$ need to understand the dependencies of those reasons on the socio-political context in which they occur as part of legal practice. In this section, I give an account of MacIntyre's understanding of a social practice, and sketch the relationship of the different social practices within a political community to a political common good. This will provide the political context in which legal practice is embedded, as a form of governance by which a political community can order itself in pursuit of a political common good.

According to MacIntyre, humans learn about what ends are good to pursue by practice, with experiences of achievement and failure. That education can transform desires and enable the human agent to distinguish between ends to achieve as mere objects of desire, from ends genuinely good to desire in the circumstances. What MacIntyre calls a 'social practice' plays a crucial role. It is a social context that has a causative influence on an individual's reasons for action because in such contexts the ends to be chosen are accountable and subordinate to common ends to be achieved. Within this social context, human agents learn to distinguish what is simply an end qua object of individual desire, from what is a good end by reference to mutual standards internal to the practice. They exercise practical rationality not simply qua autonomous individual but qua self-directing participant.

MacIntyre's use of 'social practice' is quite different to how other theorists may understand that term. He defines a 'practice' as:

[...] any coherent and complex form of socially established co-operative activity through which goods internal to that form of activity are realized in the course of trying to achieve those standards of excellence which are appropriate to, and partially definitive of, that form of activity, with the result that human powers to achieve

\footnotetext{
${ }^{31}$ In this paper I assume the account of intentional action developed by MacIntyre, largely from Anscombe, Aquinas and Aristotle. He distinguishes intelligible human action from mere bodily movements by reference to purposes, which presupposes a human capacity to apprehend good reasons for acting and explain actions on this basis. The capacity to distinguish between good or bad reasons for action is objectively grounded by practical experience of performing an activity well or badly within analogous contexts, and a tradition of enquiry between human agents concerning these standards. See: Alasdair MacIntyre, After Virtue: A Study in Moral Theory (3rd edn, UND Press 2007) ch 15; Alasdair MacIntyre, 'The Intelligibility of Action' in J Margolis, M Krausz and RM Burian (eds), Rationality, Relativism and the Human Sciences (Martinus Nijhoff 1986); Alasdair MacIntyre, Dependent Rational Animals (Open Court 1999) chs 6-9; Thomas D'Andrea, Tradition Rationality and Virtue (Ashgate 2006) 171-216, 267-280. A full treatment and defence of this account of intentional action is beyond the scope of this paper, but the recent work of Rodriguez-Blanco offers a valuable contribution: Veronica Rodriguez-Blanco, Law and Authority under the Guise of the Good (Hart Publishing 2014).
} 
excellence, and human conceptions of ends and goods involved, are systematically extended. $^{32}$

Chess is an example. Think of a child, bribed to play with the promise of candy if she wins. While the bribe serves to motivate her to learn to play by the rules, she has good reason to cheat or otherwise instrumentalise the game insofar as the bribe remains the chief motivation for playing. If she learns to enjoy the standards of excellence internal to chess, including the skills and competitive challenges involved, she has good reason to internalise and act by the rules of the game. This example introduces a key distinction between goods internal to the activity of a practice and goods external to it. ${ }^{33}$ That distinction enables MacIntyre to isolate the role of mutual commitments and obligations that result from the constitutive dependency of the individual good concerned on the ends of the common enterprise. It will be crucial to understand the social nature of reasons for action within legal practice.

Internal goods are shared purposes and standards of excellence internal to the practice in that they define what it means to do the activity well and can serve as intelligible shared motivations for co-operative participation in that practice. This telos of the practice may involve a complex range of different satisfactions experienced in performing the activity well. But the pleasure from the activity is not the good itself. '[E]njoyment supervenes upon the successful activity in such a way that the activity achieved and the activity enjoyed are one and the same state' - pursued together. ${ }^{34}$ Internal goods incorporate the extension of human skills, capacities and virtues involved in the activity, as well as the activity done well and any consequent product. ${ }^{35}$ These are common goods because 'their achievement is a good for the whole community who participate in the practice'. ${ }^{36}$ In other words, internal goods are at least partially shareable rather than mutually exclusive, and shareable in the sense that their achievement by one benefits the whole practice. Achieving them requires mutual commitments to the internal standards of success for the common enterprise. ${ }^{37}$

\footnotetext{
${ }^{32}$ Macintyre 'After Virtue' (n 31) 187.

33 ibid 188-190.

34 ibid 197.

${ }^{35}$ MacIntyre does not follow Aristotle in separating praxis (action) from poiesis (production), and therefore phronesis (rational orientation to action) from techne (rational orientation to production). He treats the product of an activity as internal to the activity, allowing him to incorporate the skills developed to sustain good production within his virtue ethic: Joseph Dunne, 'An Intricate Fabric: Understanding the Rationality of Practice' (2005) 13(3) Pedagogy, Culture and Society 367; Kelvin Knight, Aristotelian Philosophy: Ethics and Politics from Aristotle to MacIntyre (Polity Press 2007) 4-40, 150-156.

${ }^{36}$ MacIntyre 'After Virtue' (n 31) 190-191.

37 ibid 190-191; Alasdair MacIntyre, Three Rival Versions of Moral Enquiry (Duckworth 1990) 61-63.
} 
But are games, like chess, really analogous to other forms of social practice? ${ }^{38}$ For many social activities, we do not typically have a choice whether to participate. Also, the analogy with games may fail, as Yack argues, to capture 'the unavoidable interest in - and competition to shape - the intrinsic correctness of standards of justice in political communities because it extrapolates from the relatively limited concerns of game players' ${ }^{39}$ These are important concerns, but they do not impugn MacIntyre's analogy. He is identifying human associations with a common property. 'Social practices' have internal standards which are constitutive of and indispensable to achieving the shared ends of the activity in question. They involve standards and virtues that are constitutive of common goods to be achieved, causing the socially acceptable reasons for action of participants to be partially independent of individuals' desires. ${ }^{40} \mathrm{He}$ opposes this with mutual advantage co-operation where 'individuals, each pursuing the satisfaction of their own wants and needs, agree in accepting a rule governed framework for their activities, each with his or her individual aim of thereby protecting his or her security in the pursuit of his or her satisfactions' ${ }^{41}$ Both are instantiated in social life, and to greater or lesser degrees in different activities or in the same activity.

To illustrate what MacIntyre means by a 'practice', consider what human activities exhibit characteristics of being motivated by common goods. The examples MacIntyre gives are wide-ranging, including chess, football, farming, building, architecture, fishing, painting, sculpture, poetry, drama, gymnastics, music, military service, war, medicine, mathematics, physics, chemistry, biology, history, philosophy, enduring friendships and family life, law, religion, politics, and ethics. Some are productive, some games, some intellectual enquiries, and some concern healthy communal life. Many exhibit interdependencies with other practices. Their internal standards may either constitute or depend on achievements in other practices. ${ }^{42}$ For example, as I will argue, the ends of politics constitute standards internal to legal practice; and architectural standards rely on possible achievements in construction. Still, each activity is structured, in its particular form, by shared standards of excellence that provide reasons for individuals to act as co-operative participants. They contrast with

\footnotetext{
${ }^{38}$ Bernard Yack, The Problem of a Political Animal: Community, Justice, and Conflict in Aristotelian Political Thought (UCP 1993) 58-62; David Miller, 'Virtues, Practices and Justice' in John Horton and Susan Mendus (eds), After MacIntyre: Critical Perspectives on the Work of Alasdair MacIntyre (Polity Press 1994) 249-252.

${ }^{39}$ Yack (n 38) 61.

${ }^{40}$ Alasdair MacIntyre, 'A Partial Response to My Critics’ in Horton and Mendus (n 38) 284-286.

${ }^{41}$ Alasdair MacIntyre, 'Rights, Practices and Marxism' (1985) 7 Analyse \& Kritik 234, 241.

42 MacIntyre 'Three Rival Versions' (n 37) 67-68.
} 
associations, like investment clubs or other partnerships, which may exhibit mutual advantage rationality because they are means for achieving the separable ends of partners. ${ }^{43}$

Acting on mutual advantage in a practice has the effect of instrumentalising the practice for individual ends, only contingently related to its shared standards. Thus, MacIntyre distinguishes internal goods from characteristic external goods, like prestige, status, power, and money. ${ }^{44}$ External goods may follow from successful participation in practices, but they need not. They provide vital resources for developing practices, but they do not define the internal standards of success. Further, the possession and enjoyment of external goods by one person tends to be mutually exclusive to that of another, making them potential objects of rivalry that undermine the necessary co-operation in a practice. An individual practice is always in danger of being instrumentalised for external goods in ways that corrupt and undermine its common ends. Whether or not this is a bad thing will depend on the priority to be given to the internal goods of that individual practice as a constituent part of individual or communal life. But internal goods need to be pursued for their own sake, not simply as means for attaining external goods, if we are to adequately internalise those reasons for action supporting the achievement of the shared purposes as our own reasons.

The difference between the co-operative activity itself and its authoritative direction leads MacIntyre to differentiate between practices and institutions. ${ }^{45}$ The practice is the constitutive activity itself, whereas its institutional form develops to support that activity by enforcing institutional rules and administering external goods for the benefit of the practice. Practices typically require institutional form to be sustained. But institutions are always in danger of being dominated by a bureaucratic rationality, or corrupted in ways that orientate them towards external goods as the predominant end. In these circumstances, institutional rules may no longer embody or support the 'rules of the practice' which reflect the general standards of conduct conducive for achieving its internal goods. ${ }^{46}$ This instrumentalises the practice for exterior purposes and creates a conflict with the practical rationality motivating the mutual commitments of participants.

To external observers, a practice may seem to be constituted by its institutional rules and form. But it is not the rules per se that define a practice. Rules change and develop to improve its functioning. The internal goods provide standards by which the rules can be

\footnotetext{
${ }^{43}$ Alasdair MacIntyre, 'Politics, Philosophy and the Common Good' in Kelvin Knight (ed), The MacIntyre Reader (Polity Press 1998) 239-240.

${ }^{44}$ MacIntyre 'After Virtue' (n 31) 188, 190-191, 196.

45 ibid 194-195.

${ }^{46}$ MacIntyre (n 7) 29.
} 
evaluated, even when those rules might be constitutive means for achieving those internal goods. Consider, for example, the rules of chess. Those rules constitute the competitive standards of success involved, but it is the value of those rules in enabling the competitive challenges which provides the point and purpose of the rules. The internal goods and rules of the game may be mutually constitutive, but the internal goods provide reason for rulefollowing. When a participant's motivation for engaging in a practice fixates on external goods, the binding authority of institutional rules, and the officials and institutions applying those rules, will have primary significance for orientating their action in the practice. ${ }^{47}$ This follows from the inability to fully internalise the goods of the practice as reason for conformity with the rules. If a chess player wants to quit because she unwittingly made a bad move, she is only following the rules to win and not for the shared standards of the game. In contrast, a participant motivated by internal goods will recognise the rules and requisite virtues as constitutive means for co-operating with other participants to achieving them. ${ }^{48}$ This allegiance to the joint enterprise secures commitment to the virtues of a good practitioner and to the mutual standards of the practice.

The conduct and motivations of a participant can be held accountable by other participants through the giving and receiving of reasons for action. ${ }^{49} \mathrm{We}$ can ask other participants why they acted in the way that they did, and hold the reasons that they give accountable to the shared standards of the practice if they are committed to being a cooperative participant. The standards for judging such reasons derive from the shared standards of achievement in the practice. These standards are refined by the experience of what is most conducive to the practice functioning well over time, by reference to the achievement of its internal goods. Thus, the material conditions of a practice, with its institutional form, are transformed through thought and discourse into a tradition. ${ }^{50}$ So, for example, within legal practice the judge deciding a case will be informed by past judicial thought on the legal issues at stake. In the same way, the understandings of law expressed by Hart have an intelligible relation to those of Austin and Bentham, and even to Aquinas. Understandings of a practice can be understood and debated between contemporaries and through different generations of participants. The systematic extension and transformation of the internal goods of a practice are connected to this dialogue between participants over time

\footnotetext{
47 ibid 28-30.

${ }^{48}$ MacIntyre 'After Virtue' (n 31) 190.

49 ibid 217-218; MacIntyre 'Dependent Rational Animals' (n 31) 107.

${ }^{50}$ MacIntyre 'After Virtue' (n 31) 193-194; Alasdair MacIntyre, 'Epistemological Crises, Dramatic Narrative and the Philosophy of Science' in Alasdair MacIntyre, The Tasks of Philosophy: Selected Essays, Volume 1 (CUP 2006).
} 
concerning the best understanding of its standards so far and how to best achieve them. There is a continual engagement between the understanding of a practice by its participants and the experience of an activity's functioning.

Now we need to place what has been said about 'social practices' in the context of individual and communal life to appreciate how MacIntyre would understand politics as a social practice aiming at a political common good. The concept of a 'social practice' identifies activities in which constituents of the overall good of an individual are dependent on a co-operative social life. MacIntyre contextualises the web of interdependent social practices and activities a person engages in, some chosen and some not, within a narrative life structure. ${ }^{51}$ The capacity for practical reasoning allows the human agent to extrapolate from their reasons for particular actions, in pursuit of particular goods, to thinking more abstractly about an overall good that can guide the attainment of more immediate goods in the context of the life they desire to live. ${ }^{52}$

According to MacIntyre, the ordinary person cannot avoid raising the questions: 'What is my good?' and 'How is it to be achieved?' Competing desires prompt decisions between different proximate ends, and opposing demands from different practices and activities require consideration of the part each will have in her life. These decisions may form as implicit presuppositions to the activities and motives characterising how she comes to live her life by inclination. However, the counterfactual, of what she would have done had she been better informed about her overall good and its significance for her immediate actions, is always relevant for evaluating her action. In other words, her capacity to instantiate greater directedness in achieving her overall good is always relevant. That greater directedness requires some degree of deliberation, perhaps through critical reflection on her past actions and narrative so far. At different points in her life, circumstances will prompt her to question the overall good to which she is committed so far and redirect her intentions and desires in developing her life narrative by future action. The articulation and experience of this narrative unity can be lacking, but it is necessary for humans to flourish with purposiveness to their life. ${ }^{53}$

\footnotetext{
${ }^{51}$ MacIntyre 'After Virtue' (n 31) 204-225; MacIntyre 'Three Rival Versions' (n 37) 127-145.

52 MacIntyre 'After Virtue' (n 31) 207-219; MacIntyre 'Three Rival Versions' (n 37) 61-63; Alasdair MacIntyre, 'Plain Persons and Moral Philosophy' in Knight (n 43); MacIntyre 'Dependent Rational Animals' (n 31) 53-79; Alasdair MacIntyre, 'Intractable Moral Disagreements' in Lawrence Cunningham (ed), Intractable Disputes about the Natural Law (UND Press 2009) 12-14, 17-18, 12-14, 17-18, 335-337; Alasdair MacIntyre, 'Rival Aristotles: Aristotle Against Some Modern Aristotelians' in Alasdair MacIntyre, Ethics and Politics: Selected Essays, Volume 2 (CUP 2006).

${ }^{53}$ Alasdair MacIntyre, 'Positivism, Sociology, and Practical Reasoning: Notes on Durkheim's Suicide' in Alan Donagan, Anthony Perovich and Michael Wedin (eds), Human Nature and Natural Knowledge (Kluwer 1986);
} 
This describes what MacIntyre calls the 'narrative quest' of each human being for an overall good. That narrative is grounded in the roles, experiences, and character formation provided in social practices and the material conditions of the human being. ${ }^{54}$ The human identity is not reducible to the roles played in social practices; however these practices play an integral part in constituting the human character over time, and grounding future aspirations. MacIntyre's narrative structure, therefore, identifies a teleological character to human life extending beyond social practices in pursuit of an overall good, but crucially depending on social practices for constituents of this good. The commitment to a life narrative which encompasses the internal goods of different social practices means that the individual is also committed to achieving a political common good as an important part of their own good.

Thus, the question 'What is my good?' can often implicate the question 'What is our good?' The need to order the different activities and practices as part of a political community gives rise to a need for joint practical reasoning through political discourse if answers to these questions are to be pursued co-operatively. ${ }^{55}$ MacIntyre asks us to consider a political community that:

[...] exists for the sake of the creation and sustaining of that form of communal life into which the goods of each particular practice may be integrated so that both each individual and the community as a whole may lead a life informed by these goods. ${ }^{56}$

MacIntyre believes that the need for individuals to sustain co-operative relations in different social practices requires a corresponding social commitment to sustain this form of political community. As a consequence, political activity becomes normatively structured as a 'social practice', with a telos constituted by the need for political co-operation to achieve certain common ends. These common ends, or internal goods to political practice, are associated with the task of integrating the different practices of a political community, for the good of that community and as the social conditions for individual human flourishing. MacIntyre refers to that telos as the 'political common good'. This term captures the aim to provide the best possible ordering to all the particular goods to be achieved in the community, through the integrative function of political practice. In what follows, I want to consider how we might think of law as a 'social practice', deriving the reciprocity which Fuller describes from

Alasdair MacIntyre, 'Can One Be Unintelligible to Oneself?' in Christopher McKnight and Marcel Stchedroff (eds), Philosophy in its Variety (Queen's University Belfast 1987).

${ }_{54}$ MacIntyre ‘After Virtue' (n 31) 215-220; MacIntyre 'Dependent Rational Animals' (n 31) 81-128.

${ }^{55}$ MacIntyre (n 43); MacIntyre 'Dependent Rational Animals' (n 31) 113-146.

${ }^{56}$ Alasdair MacIntyre, 'Practical Rationalities as Forms of Social Structure' in Knight (n 43) 123. 
its supporting role for the pursuit of this political common good. My claim is that this can provide the necessary political background to explain why we should accept Fuller's argument that legal practice is necessarily conditioned by 'political reciprocity'.

\section{LAW AS A SOCIAL PRACTICE}

Despite notable efforts to account for the relationship between law as 'reason for acting' and law as 'social phenomenon', ${ }^{57}$ there is still insufficient attention given to the role of sociality in legal practice and the intelligibility of reasons for action within socio-political context. This lacuna forms an implicit background to Fuller's claims concerning the reciprocity that conditions the role of legal officials. MacIntyre's emphasis on human sociality can provide a helpful corrective. In particular, his concept of a 'social practice' can identify the important role of internal goods for constituting the co-operative nature of reasons for action within legal practice. This can help to make sense of the connection that Fuller draws between the purposive nature of legal activity and the reciprocity between legal participants. The activities involved in legal practice would be intelligible by reference to how participants should act to sustain the co-operative purposes of that practice - or in other words, its internal goods.

Describing law as a 'social practice' entails that it is a purposive activity performed, in some sense, together. The 'togetherness' is the key problem. My claim is that it arises from the need to achieve certain internal goods to legal activity, which can explain why the motivations and actions of participants are accountable to co-operative standards of achievement. Legal practice exhibits the co-operative rationality of a social practice because the pursuit of these goods requires a sufficient degree of mutual commitment between legal officials and subjects, embodied in social standards. In addition, the achievement of these goods can be systematically extended by an improvement in the quality and extent of this mutual commitment - what Fuller calls the fidelity to law. It is by reference to the achievement of these internal goods, and the constitutive co-operative standards for their achievement, that participants have a basis for distinguishing good and bad reasons for action within legal practice.

To consider this argument in more detail, we need to flesh out the activities involved in legal practice. The most obvious activities are the making, interpreting, and applying of legal rules to provide a form of governance that supports the practice of politics. In this sense, law is a subsidiary practice. Its purpose is derivative from its role as a distinct means for

\footnotetext{
${ }^{57}$ Finnis identified this problem in: John Finnis, 'Reason, Authority, and Friendship' in John Finnis, Reason in Action: Collected Essays: Volume 1 (OUP 2011).
} 
achieving political ends. But the achievement of these political ends, through law, requires the co-operation of legal subjects as active participants in legal practice. As described in Section B, Fuller understands the efficacy of law to be supported by the co-operative dispositions of both legal officials and legal subjects to act with fidelity to law. Of course, legal subjects may not choose whether to participate in legal practice, in the sense that a political regime can apply law through the imposition of force. But the active participation of legal subjects is still necessary for the following reasons. First, the efficacy of law, in achieving its political ends, depends on a general belief in its legitimacy by legal subjects which can sustain their co-operative obedience to legal rules as binding reasons for action. Second, that efficacy will also depend on how well legal subjects guide their individual conduct by reference to legal rules.

We can make sense of Fuller's notion of reciprocity from this supporting role that law plays for political practice. My claim is that the interdependence between the activities of legal officials and legal subjects, for achieving the ends of political practice, constitute law as a practice in the sense MacIntyre describes. Legal practice is both a purposive and cooperative activity because it involves an extension of co-operative skills, virtues, and standards of excellence to realise a political order aiming at the common good. ${ }^{58}$ The 'internal goods' of that practice are those ends that capture the common value of law, as a distinct form of governance, to all citizens in the political community. In this context, political reciprocity means that legal officials and legal subjects should act in their respective roles as participants in legal practice with an appropriate respect for these internal goods, to sustain and extend its value as a co-operative enterprise.

Consider the role of the legal subject. Within legal practice, the legal subject learns to distinguish between what is simply instrumentally good qua individual, from what is good qua legal subject. ${ }^{59}$ This practical formation differentiates between those who treat law as a binding reason for action only insofar as it is likely to be enforced; and those who grasp the value of the internal goods of legal practice as reason for them being law-abiding citizens. The practice of law is fundamental for providing the social conditions for developing and sustaining human capacities as responsible agents. This means that broader political and moral standards are relevant to the internal standards of legal practice, but in a manner particular to the role of law in society and of the person qua legal subject. The judgment of

\footnotetext{
${ }^{58}$ MacIntyre cites law as an example of a social practice: MacIntyre (n 7).

${ }^{59}$ MacIntyre 'Dependent Rational Animals' (n 31) 66-67.
} 
what is good qua legal subject thus depends on judgments of what is good qua human being in the context of law's role in a community.

These judgments qua legal subject inform what is good qua official within legal practice. The official's role is dependent on the reciprocal and justificatory relation it bears to legal subjects. If the official restricts their reasons for action to what is good qua individual, they ignore the social dependency of their actions within legal practice. When they invoke law as an authoritative reason for action, this has social significance connected to the standards for pursuing its internal goods. In particular, that authoritative reason for action is necessarily expressed as a justification to other participants, which is parasitic on a broader justification for the enforcement of law which can sustain mutual fidelity to law. ${ }^{60}$

As Simmonds points out, the judge has a paradigmatic role in law's justificatory force. ${ }^{61}$ The act of making a judgment is a social act, requiring the judge to appeal implicitly to the social reasons for action embodied in a rule, and its nature as 'law', to provide adequate justification for their judgment. This involves a type of 'reflexivity' in the practice of law, whereby the application of law as an authoritative reason for action relies on an implicit appeal to the nature or function of law as an evaluative background to its justification. Although it might be possible, as Hart allows, for an official to apply law for selfish reasons, this misses the point. The reasons provided in a judgment are subject to justificatory standards embodied in the practice. A bad application of law can be identified by reference to these standards, and this has the potential to bear on a participant's reasons for recognising its binding authority and guiding their conduct accordingly.

Given that the reasons of officials are parasitic on the justificatory standards that support the co-operative effort of legal practice, then Finnis may be right to identify a 'focal instance' of law - where law aims at the common good. However, I will understand this 'practical viewpoint', defining the 'focal instance', as that which is consistent with the shared evaluative standards for the practical reasoning of participants within legal practice. ${ }^{62}$ The internal goods of legal practice provide these intelligible justificatory standards. In what follows, I will argue that these internal goods are associated with the capacity for law to order the political community towards the political common good (the substantive morality of law),

\footnotetext{
${ }^{60}$ Rodriguez-Blanco calls this the 'parasitic thesis': that the social normativity of legal officials (the reasons for applying law) is parasitic on the notion of justified normativity: Rodriguez-Blanco (n 31) Chs 5-6.

${ }^{61}$ Simmonds (n 5) 113-143, 156-158; Nigel Simmonds, 'Reply: The Nature and Virtue of Law' (2010) 1(2) Jurisprudence 277, 289-293.

${ }^{62}$ Finnis (n 23) ch 1.
} 
while respecting legal subjects as active and responsible participants in that effort (the procedural morality of law).

\section{E. SUBSTANTIVE MORALITY OF LAW}

The substantive morality of law concerns what ends a community should pursue through law, and therefore incorporates the supporting role law plays for politics. The support of political practice is the most fundamental reason for legal activity. Without the need or desire to pursue common ends together, there would be no good reason for governance to distinguish it from arbitrary authority. Even where the reason for political community is understood by reference to its capacity to instantiate a degree of freedom for the individual to pursue their own ends, this necessarily implicates a common good that explains why there is political governance at all. In that understanding of political community, the common good is the general and stable framework of rules that can mediate between individuals to enable that freedom. ${ }^{63}$ However, if political practice is best understood as a voluntary association, based on a mutual advantage not grounded by any common good, then the reciprocity between legal officials and legal subjects must be seen as contingent. It cannot be a necessary feature of a legal system. This is why Fuller's procedural morality is intrinsically linked to a claim that there is some political common good that provides a justificatory basis for the political community. The importance of these political conditions for the continued existence of law, as a purposive social phenomenon, forms the background to Fuller's notion of reciprocity in legal practice.

At minimum, law is an indispensible means to achieve shared conditions for order and stability in a political community. But the reciprocity involved in legal practice is connected to the political expectation that any end pursued for the community should be capable of justification by reference to it being good for that community. The ordering of the community by law for achieving the common good provides the practical context from which the goodmaking characteristics of a law can be identified and brought to bear on law-making, interpretation and application. It informs the rationale of a law, providing the practical evaluative context necessary for officials and legal subjects to rationally engage with what legal rules require in concrete circumstances.

\footnotetext{
${ }^{63}$ A number of liberal theorists have emphasised that liberal political community is structured by a conception of the common good: John Rawls, A Theory of Justice (Original edn, HUP 1971) 228-234, pt 3; Will Kymlicka, Liberalism, Community and Culture (OUP 1989) 75-79; William Galston, Liberal Purposes: Goods, Virtues and Diversity in the Liberal State (CUP 1991) 72-74, ch 8.
} 
Central to an understanding of law is an appreciation of what it means for legal practice to function well as a purposive activity. I am arguing that this 'functioning' needs to be understood in light of the functioning of a co-operative political practice. Thus, we need to appreciate the functioning of legal practice by reference to the situation when laws aim, in good faith, to achieve a shared understanding of the common good. In those circumstances, by understanding the practical good-making reasons for a law, it is possible for the legal subject to apprehend the communal ends the law is designed to achieve, as good ends for them to pursue qua citizen and for their own overall good. The legal subject can make these communal ends their own, and thereby participate more fully in a shared understanding of the political common good.

The extent of that participation does not stop with law-abiding citizens. It extends to the participation of citizens in those social virtues and goods critical for a co-operative form of political community. ${ }^{64}$ Laws against littering, for example, can be internalised as communal standards reaching beyond their legal ambit to promote communal cleanliness. Like the child who learns to play by the rules of chess for the excellence of the game, it is possible for the legal subject to be formed through law to standards of communal excellence. Legal practice, therefore, can involve the systematic extension of skills, capacities and virtues of lawmakers, judges, lawyers, and citizens, facilitating the realisation of the common good through law. This extension is reinforced by the internalisation of that common good by legal subjects as an intrinsic (rather than extrinsic) standard and essential ingredient for their own flourishing.

This understanding of what it means for law to function well, in establishing and sustaining a co-operative form of political community, is fundamental to the purposive and co-operative nature of legal practice. Without this type of claim about the purpose of legal practice, Fuller is not able to establish the necessary importance of reciprocity to legal practice, as a co-operative social activity. As a consequence, he cannot establish his case for a necessary connection between law and morals. Instead, from Hart's perspective, it is open to interpret his debate with Fuller as dependent on a prior question about the morality of a political regime. If politics is not conditioned by internal standards for achieving some form of political common good, then the concept of law must be open to the possibility that law may be used for evil. There may be some good consequences in respect of human agency because legal subjects are given the opportunity to obey. But these consequences can be

\footnotetext{
${ }^{64}$ MacIntyre 'Dependent Rational Animals' (n 31) 93-94, 108-112.
} 
treated as merely incidental to whatever reasons (including selfish reasons) a legal official may have for applying law. Following this reasoning, Kramer argues that if we impute the moral value of the common good to law we should be willing to impute wickedness - as law can be used for either. ${ }^{65}$

To respond, we need to discern different senses in which a means can be valuable. In the sense used by Kramer, a means is only valuable by reference to whatever end it is used to achieve. In a related sense, a means can be valuable as a type that has an aptitude or constitutive importance for achieving particular ends. The perfection in which this aptitude consists is not secondary, but primary to the means. Thus, the claim of a necessary connection between law and the common good does not entail that law can only be used to achieve that good. Rather, law involves an aptitude and indispensability for achieving the common good which is systematically extended by a well-ordered legal practice. The counter argument, from the legal positivist, is that law is just as serviceable for good as for evil purposes.

To decide between these two positions, we need to reiterate that law is not simply an activity engaged in by those with authority. Legal rules must be apt to provide authoritative reasons for action to legal subjects, so they may effectively guide their conduct to achieve the communal ends of the law. With this in mind, Aquinas calls a law contrary to the common good a 'perversion of law' ${ }^{\prime 66}$. As explained in Section B, Fuller is wary of the suggestion that there is any such 'higher law'. But we can explain Aquinas' 'perversion of law' by the fact that the reasons for action involved are directed towards external goods (like power) rather than internal goods to legal practice. They do not aim at a justification to all participants according to shared standards within the practice. In this way, there is what Alexy calls a 'performative contradiction' between the justificatory basis for political and legal practice, and the use of law. ${ }^{67}$ In the circumstances, the use of law objectifies and instrumentalises the necessary co-operation of other participants for contingent purposes that are not shared. Like the child playing chess for candy, the reasons for action within legal practice become relative to external purposes. Law is only treated as a social practice relative to the purposes of the ruler or government or officials, and is therefore better described as a non-focal instance, or perhaps an anti-social practice.

\footnotetext{
${ }^{65}$ Kramer 'Once More Into the Fray' (n 27) 37-38.

${ }^{66}$ Aquinas, Summa Theologiae (NovAntiqua 2014) I-II, Q92, A1.

${ }^{67}$ Robert Alexy, 'A Defence of Radbruch's Formula' in David Dyzenhaus (ed), Recrafting the Rule of Law: The Limits of Legal Order (Hart Publishing 1999) 26-28.
} 
The possibility of serviceability for extrinsic purposes does not impugn the fact that law is a co-operative activity that presupposes constitutive commitments to internal standards by which this instrumentalisation can be judged. In the same way, while a friendship may be useful for extending one's professional network, the use of a friend merely for this end can be judged to affect the quality of friendship by the standards of reciprocity implicit in friendship. Both law and friendship are co-operative practices which bring internal standards to bear on the actions and reasons of the participants. It is only by abstracting from the nature of law as a social practice, with a socio-political reciprocity sustained by the common task of achieving a common good, that Hart can describe law as merely instrumental for the isolated reasons of officials who use it. As the analogy of friendship depicts, the use of law in this way, based on reasons that abstract from the purposive social activity, does not cease to be subject to the critical practical standards of that social activity.

\section{F. PROCEDURAL MORALITY OF LAW}

In contrast to the substantive morality of law, which involves the aptitude of law for achieving a wide variety of communal ends, the procedural morality of law is connected to specific ends with moral value. These specific ends are associated with how human persons should be bound to the common ends of a political community.

Finnis subsumes this procedural morality within his substantive morality of law, based on his theory of the common good and justice. ${ }^{68} \mathrm{He}$ thereby provides a corrective to Fuller's attempts to distinguish his procedural morality as internal to legal activity from the substantive ends of law as more external to legal activity. ${ }^{69}$ The substantive ends of law do become an internal part of the activity and form of legal governance. If this were not the case, there would be no reason to claim that the reciprocity between officials and legal subjects, grounded by the common good, is a necessary feature of the proper functioning of legal practice. The substantive ends of particular laws may be diverse, but it is the capacity for those ends to be understood and justified as constituents of a common good that sustains the reciprocity in legal practice.

Nevertheless, Fuller is right to clearly differentiate the role of his procedural morality of law. Subsuming it within the substantive morality of law obscures the distinct relationship between law and the precepts of legality, compared to the variety of ends for which laws are made. In addition, it can perhaps confuse law as a distinct means, compared to other means

\footnotetext{
${ }^{68}$ Finnis (n 23) 272-273; John Finnis, 'Law as Idea, Ideal and Duty' (2010) 1(2) Jurisprudence 245, 250.

${ }^{69}$ Fuller 'Morality of Law' (n 1) 97.
} 
for governance, by which a political community might direct the actions of its citizens to those common ends. ${ }^{70}$ It is therefore important to recognise the distinct role of co-operative standards, formed in response to the question of how human persons ought to be bound to communal ends, for shaping the institutional form of law.

My claim is that the eight precepts are rules of legal practice, or good legal craftsmanship, which are intelligible by reference to the achievement of internal goods associated with this moral question. These internal goods are of a secondary order because they presuppose communal ends to which citizens should be bound. The question of how to bind follows upon authoritative political decisions concerning what substantive ends law should pursue. Hart's description of secondary rules is helpful here. The eight precepts of legality involve rules 'about rules'. ${ }^{71}$ They are rules that structure the crafting and administration of law within legal practice.

We need to depart from Hart, however, to stress that these 'rules about rules' develop according to practical reasoning about how laws should be crafted and administered to sustain the co-operative pursuit of internal goods to legal practice. They are only fully intelligible as part of legal practice if we can explain the common value of these principles of legality for all participants in the practice, and thus why participants should be committed to acting co-operatively to sustain fidelity to these principles. What then is the common moral value of these eight desiderata?

Simmonds claims that the rule of law instantiates the moral value of freedom as independence. $^{72}$ This aspect of freedom is not concerned with the range of options available to an agent, but with whether such options are subject to the direct will or power of another. It 'distinguishes the slave from the free man' and is realised, Simmonds argues, to the extent we are governed by law complying with the eight desiderata. ${ }^{73}$ This way of describing the moral value underpinning the rule of law can be contrasted with an account that would also underscore the potential enhancement of responsible agency. Missing from Simmonds' freedom as independence is a treatment of the capacity for the agent to participate in the practical rationality of a law and to act on an understanding of why it is good for them. In what follows, I will argue that the eight desiderata can enhance both freedom as independence and the capacity for responsible agency. The two are not mutually exclusive

\footnotetext{
${ }^{70}$ Fuller 'Fidelity to Law' (n 1) 645; Simmonds (n 5) 182-189; Nigel Simmonds, Value, Practice and Idea' in John Keown and Robert George (eds), Reason, Morality and Law: The Philosophy of John Finnis (OUP 2013) 324-325; Jeremy Waldron, 'The Concept and the Rule of Law' (2008) 43 GLR 1, 61.

${ }^{71}$ Hart (n 2) 94-99.

${ }^{72}$ Simmonds (n 5) 99-111.

${ }^{73}$ Simmonds (n 61) 21-22.
} 
and can be captured within a broader account of freedom, which I call 'freedom as dominion'. However, the degree to which the rule of law can instantiate the more limited 'freedom as independence' or a broader 'freedom as dominion' depends crucially on what differentiates a focal instance from a non-focal instance of law - whether law aims at the common good.

In my opinion, the instantiation of a focal instance of law, realised by the ordering of legal subjects to understand and act for the common good, allows for the rule of law to achieve a form of 'freedom as dominion' for legal subjects. ${ }^{74}$ This is more consistent with Fuller's claim that 'the enterprise of subjecting human conduct to the governance of rules involves of necessity a commitment to the view that man is, or can become, a responsible agent, capable of understanding and following rules, and answerable for his defaults'. ${ }^{75}$ Freedom as dominion involves the ability of human agents to develop an understanding of the overall good for their life and to exercise rational direction over their action to achieve that overall good within their community. It includes the capacity to act and flourish as responsible agents, as well as the degree of liberty to choose between different options falling within this rational direction. However, it also includes freedom as independence because the experience of our rational dominion has a dependency on the extent to which it is subject to the will of another person.

Together, these dimensions of freedom as dominion derive from the human capacity to be what MacIntyre calls independent practical reasoners. ${ }^{76}$ The capacity for independent practical reasoning enables human beings to comprehend the practical rationality of law and to put law into practice. No rule can treat all potential contingencies and all rules require practical reason to determine their application to particulars. ${ }^{77}$ Independent practical reasoners, though, have the capacity to determine whether or not and in what way a rule applies to specific actions and to guide their conduct in following a rule. This requires them to understand how a rule might apply to their performance of an action given a broader normative understanding of the potential grounding reasons for that rule and the way those reasons apply to action in different factual circumstances. As a consequence, the independent practical reasoner is able to direct themselves to the ends of a particular law, guided by the

\footnotetext{
${ }^{74}$ Freedom as dominion is fundamental to Aquinas' definition of 'person' as 'rational substances which have dominion over their own actions': Aquinas (n 66) I, Q29, A1. See also: I-II, Q1, A1, A2; Q96, A4.

${ }^{75}$ Fuller 'Morality of Law' (n 1) 162. See also: Fuller 'Morality of Law' (n 1) 42-43, 162-163; Lon Fuller, 'Freedom as a Problem of Allocating Choice' (1968) 112(2) Proceedings of the American Philosophical Society 101; Lon Fuller, 'Freedom: A Suggested Analysis' (1955) 68 HLR 1305.

${ }^{76}$ MacIntyre 'Dependent Rational Animals' (n 31) 71-76, 81-98.

77 ibid 93; Alasdair MacIntyre, 'Does Applied Ethics Rest on a Mistake?' (1984) 67(4) The Monist 498.
} 
potential grounding reasons for that law. Consider the following example given by Rodriguez-Blanco:

Let us suppose that we are climbing a mountain guided by an expert. Before we start climbing, he gives us a set of basic safety rules such as 'do not pull the rope', 'do not pass the person who is ahead of you', and so on. We begin climbing and do what he tells us to do, he shouts 'throw the rope', 'put on the harness', 'small and steady steps, please', 'don't look back'. We follow the successive steps of the action 'climbing the mountain' following the safety rules. But whilst doing the actions my harness breaks and I need to adjust my conduct. I take my scarf off and make a harness with it. If I am asked why did you do that? The naïve or basic answer is 'I needed to be safe'. To be safe when one climbs is the grounding reason or logos of the set of rules for climbing safely. Therefore, what guided me in my actions was not the rule, but a set of facts about the world together with a grasping of the grounding reasons as goodmaking characteristics of the rules, ie it is good to be safe.

This example points to the importance of law for active guidance of individual human conduct to the achievement of communal ends. Rule by law can provide an effective means to co-ordinate the diverse projects and actions of individuals in a community precisely because of this capacity for individuals, as responsible agents, to guide their conduct by what they take to be the grounding reasons for particular laws. ${ }^{78}$

The enhancement of that guiding function of law can make sense of the moral value of the eight desiderata. Take, for example, the requirements that law be as intelligible as possible. The capacity for legal subjects to guide their action by the law is enhanced by the extent to which law fulfils these requirements. Legal subjects will find it easier to understand the grounding reasons for a law, and thereby guide their action in accordance with the communal ends at stake by making those ends their own. ${ }^{79}$ Thus, the value of the eight desiderata can be rendered intelligible as part of the co-operative endeavour to enhance this potential for legal subjects to understand and guide their conduct by the practical rationality (or grounding reasons) of legal rules. In this way, the procedural morality of law is connected to its substantive morality. The eight desiderata are part of the form of law that conditions its aptitude for directing legal subjects to the common good. That aptitude entails the fulfilment of a degree of freedom as dominion for legal subjects. If law is to serve its function as

\footnotetext{
${ }^{78}$ Rodriguez-Blanco (n 31) 38-39. Consider also the example given by Simmonds of the guidance of conduct by the rule: 'Dogs must be carried on the escalator': Nigel Simmonds, 'Between Positivism and Idealism' (1991) 50(2) CLJ 308, 311-312.

${ }^{79}$ Rodriguez-Blanco (n 31) ch 7.
} 
guiding individual conduct to the achievement of communal ends, then its rules should be crafted in accordance with the eight desiderata, and thus in a way that respects human beings as responsible agents who can consider how to best order their actions and projects for achieving the communal ends at stake.

This respect for the rational dominion of legal subjects is not simply instrumental for law's efficacy. It is also indispensible to the common good and constitutive of normal human flourishing. ${ }^{80}$ The crafting of law in closer compliance with the eight desiderata provides greater freedom as dominion for the citizen to order her life narrative, toward her overall good and in relation to her understanding of the common good (based on the substantive content of law). The instantiation of this freedom as dominion forms part of the substantive morality of law because it is an indispensible constituent of the common good in its own right. But it may also be distinguished from other communal ends, as specific to the secondary rules that structure the institutional form of legal practice. This captures Fuller's central claim, that the institutional form of law instantiates a respect for human agency in a way that marks out the rule of law as having distinct value compared to forms of governance that move away from fidelity to general rules, towards the 'rule of men'.

Of course, an official's motivations for complying with the rule of law may ignore this value for political effectiveness. But, as Fuller argues, these instrumental motivations have a reciprocal connection to the motivations of other participants, including legal subjects partly motivated by the cultivation of their own rational dominion within legal practice. The official is engaged in the giving and receiving of reasons within legal practice. If the reasons they offer cannot provide an intelligible justification to legal subjects, they may erode the cooperative functioning of the practice and the mutual dispositions to act with fidelity to law, in support of law's efficacy.

\section{G. LAW AS AN ANTI-SOCIAL PRACTICE}

Fuller appreciates that a theory of good legal order, and therefore legal pathology, follows upon understanding law as a co-operative social practice. The problem is that an appreciation of what constitutes a good or bad legal order does not simply follow from an understanding of the procedural morality of law. The pursuit of a political common good is the basis for mutual commitments to rule by law, and consequential commitments to principles of legality that serve this common good in considering how human persons should be directed and

\footnotetext{
${ }^{80}$ MacIntyre 'Dependent Rational Animals' (n 31) 64-65, 105-114.
} 
bound to act for the common ends embodied in law. By placing Fuller's claims within this socio-political background, we can support his notion of reciprocity as internal (rather than contingent) to the social phenomenon of legal practice, and reinforce his argument that Hart cannot distinguish law in its focal sense from legal pathology.

What constitutes an anti-social practice? MacIntyre's distinction between internal and external goods allows us to conceptualise the non-focal instance of law as an objectification and instrumentalisation of legal practice. The co-operative activity of legal subjects is objectified by the de-personalising treatment of legal practice as a mere tool. This reflects a failure to recognise the justificatory basis for action within legal practice by reference to the need to sustain a co-operative mode of political governance to pursue a political common good. ${ }^{81}$ It also indicates a failure to appreciate what Fuller calls the human dignity of legal subjects as responsible human agents and participants in legal practice. The practice is instrumentalised by its use for extrinsic ends, only contingently related to its co-operative nature. The external good of power becomes particularly relevant for an authority that seeks to use law for extraneous purposes which are divorced from any justification to citizens. ${ }^{82}$

In wicked regimes, there will be various laws that are contrary to widespread understandings of the common good shared by legal subjects, and that violate principles of justice that are fundamental for sustaining the co-operative relations of legal practice. ${ }^{83}$ The obedience and fidelity of legal subjects to such unjust laws can only be maintained for reasons extraneous to the internal goods of law and therefore contingently connected to its co-operative activity. It may be, for example, that the preference of tyranny to anarchy or the threat of force can maintain the normative force of law as a reason for action for citizens. But these reasons are only a contingent justification for continued fidelity to that law. In these circumstances, we may still say that there is governance by law if that governance is constrained, to some degree, by Fuller's principles of legality. ${ }^{84}$ However, that governance will be parasitic on a justificatory relationship to legal subjects which is only maintained by reasons for obedience that are generally incidental to the pursuit of a political common good. Thus, Aquinas describes the citizen's participation in an unjust law as participation in the

\footnotetext{
${ }^{81}$ ibid 108-109, 140-141.

82 ibid 102-103.

${ }^{83}$ This does not entail that positive law will or should lose its intra-systemic legal force, or even its moral bindingness, under an anti-social practice. A tyranny may provide good reasons for compliance with law. The point is that these reasons become increasingly contingent to the internal goods of the practice. See: Finnis (n 23) 354-362; Thomas Aquinas, De Regno (The Pontifical Institute of Mediaeval Studies 1949) Ch VI, Ch X; Aquinas (n 66) I-II, Q96, A4.

${ }^{84}$ Fuller 'Morality of Law' (n 1) 38-41, 122-123, 197-200; Fuller 'Fidelity to Law' (n 1) 660.
} 
achievement of a good relative to the particular authority. ${ }^{85}$ Legal practice essentially becomes anti-social by the appropriation of its co-operative activity for purposes that do not aim to be shared reasons.

However, a vestige of the procedural morality of law may remain. In the non-focal instance, the rule of law cannot promote a more expansive freedom as dominion for all citizens. In general, citizens will be less able to understand the potential grounding reasons for the law as aiming at the common good. As a result, many will be excluded from the benefits of that aspect of freedom as dominion that can follow from being able to apprehend and act on the communal ends of the law as constituents of their overall good. Nevertheless, as Simmonds recognises, " $\mathrm{t}$ ] $\mathrm{o}$ be governed by law is to enjoy a degree of independence from the will of others ${ }^{86}$ even within an anti-social legal practice. Since laws must be generally prospective with a degree of continuity, there is a degree of independence from the will of the lawmaker. This incorporates a domain of conduct subject to one's own rational dominion because 'in consisting of followable rules, the law must recognize certain areas of optional (non-obligatory) conduct, however narrowly circumscribed those areas may be' ${ }^{87}$

The freedom enjoyed within this instrumentalised legal practice is only a vestige of the broader freedom as dominion. For those legal subjects unable to apprehend and act on the communal ends of the law as constituents of their own good, any rational dominion will be experienced as mutually exclusive to the domain of obligatory conduct constrained by law's substantive content. Essentially, the anti-social legal practice and practical rationality of those legal subjects will be at cross-purposes. In these circumstances, the binding authority of law takes on particular significance as an external constraint on individual conduct because the ends are no longer rationally shared by the participants as bona fide communal ends. Nevertheless, to the extent there is still governance by law, the degree of respect for the eight precepts of legality which govern its promulgation and prospective operation provides some degree of independence.

Raz denies that this establishes any necessary connection between the rule of law and human freedom. The law, he argues, can be an instrument to enact slavery, which is the very antithesis of such freedom. ${ }^{88}$ This can be challenged on two independent grounds. The first ground is that there remains a degree of freedom as independence, as small as it may be, to the extent the eight desiderata are complied with in enacting a law creating slavery, and to the

\footnotetext{
${ }^{85}$ Aquinas (n 66) I-II, Q92, A1.

${ }^{86}$ Nigel Simmonds, 'Law as a Moral Idea' (2005) 55(1) UTLJ 61, 88.

87 ibid 90.

${ }^{88} \operatorname{Raz}($ n 29) 211.
} 
extent the terms of that slavery are defined by law. The second is that a law creating slavery breaks the particular jural relation of rule by law between lawgiver and slave. The slave no longer stands in a relation of rule by law, but one of rule by will, to the extent they have no legal rights. The quality of the particular jural relation can be a matter of degree - just as the instantation of the rule of law through the eight desiderata can be a matter of degree. And, in the same way, the rule of law may still be instantiated to some degree in the rest of the community. The law enacting slavery may be recognised and followed as law by the community of citizens who retain a jural relation with the lawgiver. ${ }^{89}$

This line of argument provides a critical rebuttal to Hart in the spirit of Fuller's jurisprudence. Even where law is used for unjust ends, it retains a connection to a specific moral value, reinforced by the co-operative justificatory basis for legal practice evident in its tradition and institutional form. The reply that a moral value, such as freedom as independence, does not necessarily bear upon the reasoning of officials for accepting and applying rules as law, misses the mark. The moral value of freedom as independence continues to inform the historically constituted standards of the practice, including its secondary rules, despite their instrumentalisation. It is instantiated as an internal justificatory standard within the practice, and embedded in its tradition and institutional form, whilst not necessarily being part of the particular reasons of an official.

We might agree with Hart. It is unfortunate such a moral value is consistent with great iniquity. Our life narrative and social practices can be caught interdependently within an unjust social order. Hart, however, renders this human condition superficial by abstracting it from its social embeddedness, along with a moral life that only makes sense within it. ${ }^{90}$ This social interdependence is underpinned within legal practice by the internal goods that provide a common motivational basis to sustain that practice by mutual fidelity to law, and therefore the justificatory standards for the actions of legal officials. In contrast, legal positivism isolates the practical reasons of lawmakers or officials from the justificatory standards that follow from the co-operative nature of legal practice. Recall Hart's poisoning analogy. Hart interprets Fuller as failing to distinguish between purposive activity and morality. But the key distinction Hart abstracts from is that law is a co-operative activity. Its purposive functioning is conditioned by moral standards; just as the art of making poison would be conditioned by moral standards within the broader co-operative activity of pharmaceutical production for the

\footnotetext{
${ }^{89}$ Simmonds (n 5) 101-102; Evan Fox-Decent, 'Is the Rule of Law Really Indifferent to Human Rights?' (2008) 27(6) Law and Philosophy 533; Rundle (n 3) 111-115.

${ }^{90}$ MacIntyre 'After Virtue' (n 31) 23, 181-225; MacIntyre 'Three Rival Versions' (n 37) 58-68; MacIntyre 'Dependent Rational Animals' (n 31) 107-114.
} 
sake of medical practice. The moral importance of these standards is are intensified by the act that legal subjects cannot typically choose to extricate their life narrative from political and legal practice.

As argued in Part C, there are some ends that are part of the overall good of individuals which can only be achieved through political practice aiming to achieve a political common good. This provides the reason for political governance as a legitimate cooperative enterprise, as opposed to an instrument for social control which only rests on incidental reasons for obedience. In this justificatory context, the rule of law is a constitutive form of governance by which the development and exercise of human capacities, as independent practical reasoners, can be respected as much as possible, even in circumstances of disagreement about the common good. It thereby sustains and extends the mutual fidelity of citizens to that form of political governance.

By applying MacIntyre's concept of a 'social practice' to law, we can identify a fundamental mistake in legal positivism. It conflates the pursuit of goods internal to legal practice with the instrumentalisation of legal practice for external goods. Legal positivists do this by abstracting from the co-operative nature of legal practice as a social practice. Nevertheless, even though this instrumentalisation of legal practice may undermine the intentional link between the rule of law and common good, and corrupt the internal good of rational dominion; there remains a vestige of law's adeptness for the common good that flows from its nature as addressing the practical intellect of legal subjects. This is the degree of freedom as independence, however thin, that governance by law secures for citizens to pursue their own life narrative despite the purposes of an unjust regime.

\section{H. CONCLUSION}

This paper has argued that the reliance of Fuller's procedural legal morality on political reciprocity implicates an important dependency on the pursuit of a political common good which can explain that reciprocity as a necessary feature of legal practice. Without an adequate treatment of why political practice should be understood as an intrinsically cooperative activity, Fuller's thought remains open to positivist rejoinders that would treat this reciprocity as an incidental feature of law, and not a necessary justificatory basis to sustain the actions of legal officials. Legal positivists can thereby claim that the rule of law has no necessary connection to morals because law can be used for good or evil purposes. To establish Fuller's claims about the necessary moral value of the rule of law, I have argued that we need to understand law as a 'social practice' in the sense defined by MacIntyre. This 
provides the necessary socio-political context to explain why and how legal practice is conditioned by political reciprocity. By applying MacIntyre's distinction between internal and external goods, legal positivism can be understood as confusing law as a co-operative social practice with the instrumentalisation of legal practice by officials.

Ultimately, the issues in dispute turn on how we understand the conditions of human sociality that provide the intelligible context to the human activity of law. This is where MacIntyre's conception of a social practice and a political common good is helpful for Fuller's case. But, if we take MacIntyre's critique of modernity seriously, an instrumentalist understanding of law in modern jurisprudence might reflect a deeper pathology in our cultural understanding and engagement in existing practices within liberal modernity. We might well ask: to what extent can the modern state provide for an institutional form to legal practice that can support law in the focal instance? This question, which I raise for future reflection, does not query the conceptualisation of law as a social practice articulated in this paper. It queries the extent to which modern legal practice, within contemporary liberal societies, is either well ordered to its internal goods or systematically instrumentalised. It is a critical question for understanding how MacIntyre's political philosophy would relate to existing legal practice, and the extent our political order provides for a broader freedom as dominion or a narrow freedom as independence through the rule of law. ${ }^{91}$ The instrumentalisation of the rule of law noted in legal theory could point to a deeper pathology in our socio-political context. ${ }^{92}$

\footnotetext{
${ }^{91}$ MacIntyre (n 56); MacIntyre 'Dependent Rational Animals' (n 31) 130-135; Alasdair MacIntyre, 'Is Patriotism a Virtue?' in Derek Matravers and Jonathan Pike (eds), Debates in Contemporary Political Philosophy: An Anthology (Routledge 2003); Alasdair MacIntyre, 'Replies' (2013) 264(2) Revue internationale de philosophie 201; Knight (n 35) 167-189; Thomas D'Andrea, 'MacIntyre e il problema della practica malvagia' (2004) Da Re and De Anna 203; Keith Breen, 'The State, Compartmentalization and the Turn to Local Community: A Critique of the Political Thought of Alasdair MacIntyre' (2005) 10(5) The European Legacy: Toward New Paradigms 485; Thomas Hibbs, 'MacIntyre, Aquinas and Politics' (2004) 66(3) The Review of Politics 357; Thomas Osborne, 'MacIntyre, Thomism and the Contemporary Common Good' (2008) 30 Analyse \& Kritik 75; Mark Murphy, 'MacIntyre's Political Philosophy' in Mark Murphy (ed), Alasdair MacIntyre (CUP 2003).

${ }_{92}$ Alasdair MacIntyre, Whose Justice? Which Rationality? (UND Press 1988) 344. See also: Brian Tamahana, Law as a Means to an End: Threat to the Rule of Law (CUP 2006).
} 